practices are associated with distinctive aspects of the value-based orientations of their religions. The author finds out the correlation between parental attitudes towards their children in families of different confessions and their value orientations. Keywords: value orientations, parental attitude, Jew, Muslim, Orthodox, confession

СТРОГАНОВ Алексей Валерьевич - аспирант кафедры истории и регионоведения Московского гуманитарного университета (111395, Россия, г. Москва, ул. Юности, 5; stroganovalexey@yahoo.com)

\title{
РОЛЬ ДУХОВЕНСТВА В КРЕСТЬЯНСКОМ ПРОТЕСТЕ В ПЕРИОД КОЛЛЕКТИВИЗАЦИИ
}

\begin{abstract}
Аннотация. В статье представлена интерпретация взаимоотношений государственной власти и духовенства в условиях объявленного в СССР “великого перелома», положившего начало сплошной коллективизации. На основе архивных материалов и документальных изданий констатируется, что масштаб репрессий в отношении сельских священников несопоставим с таковым в начале 1930 г., следствием чего явился массовый протест духовенства против политики советской власти в отношении церкви. Однако борьба за существование с привлечением на свою сторону крестьянских масс нередко сочеталась с проявлениями покорности духовенства по отношению к репрессивной государственной политике. Ключевые слова: коллективизация, российская деревня, государство, власть, протест, сельское духовенство, церковь, крестьянство
\end{abstract}

B современной исторической литературе изучение различных сюжетов советской истории, имеющих трагическое содержание (в частности, история сталинизма), не сводится только к описанию конкретных фактов. Исследователи перешли к представлению отечественного опыта, основанного на исторических уроках: сегодня актуальна репрезентация закономерностей, тенденций, основанная на интерпретации, осмыслении, понимании событий, явлений, процессов прошлого [Васильев, Шепелев 2016].

Одной из таких тем является изучение взаимоотношений государственной власти и различных социальных слоев российской деревни. Феномен протеста российского духовенства в эпоху «великого перелома», объявленного в 1929 г., занял важное место в общей структуре сопротивления крестьянства проводимой Советским государством политике коллективизации сельского хозяйства, при этом очень часто становясь «мотором» общего протеста.

В письме В.И. Ленина членам политбюро ЦК ВКП(б) о политике в отношении церкви от 19 марта 1922 г. лидер правящей партии утверждал: Если необходимо для осуществления известной политической цели пойти на ряд жестокостей, то надо осуществлять их самым энергичным образом и в самый короткий срок» [Алешкин, Васильев 2012: 53-54].

С началом коллективизации некоторые церковные иерархи пытались умилостивить Советское государство. Так, в начале 1930 г. в Рязанский окружком Московской области поступила докладная записка, в которой упоминалось об обнаруженном письме рязанского архиерея, в котором он призывал священничество не выступать с проповедями против коллективизации и быть лояльными в отношении существующей власти ${ }^{1}$.

1 Рязанская деревня в 1929 - 1930 годах. Хроника головокружения: документы и материалы. М.: РОССПЭН. 1998. С. 203 с. 
Как мог воспринять подобный призыв настоятель небольшой сельской или деревенской церкви, оказавшийся под жестким надзором государственной власти в те дни? С 1928 г. домохозяйства сельского священничества, наряду с кулацкими хозяйствами, подпадали под индивидуальное налогообложение. Причем в 1929 г. величина этого налога (как и в случаях с кулаками) нередко превосходила общий доход облагаемого хозяйства за весь год. Так, священник села Нармушади Ерахтурского района Рязанского округа А.Е. Инякин в жалобе на неправильное раскулачивание написал следующее: «Сельхозналог в сумме вместе с самообложением в 331,2 рубля своевременно был уплачен, что можно видеть из окладного листа по единому сельскохозяйственному налогу на 1929-30 год... Чтобы уплатить налог и самообложение, я продал две коровы и много вещей из имущества жены, крайне ей необходимых» 1 .

Реакция рядовых представителей деревенского духовенства на подобные налоги, на обличительную кампанию со стороны местных активистов-комсомольцев на сельских сходах и собраниях, а также со страниц советской печати, на начинающееся закрытие церквей вполне очевидна. В среде духовенства быстро возникали протестные настроения, которые выражались главным образом в агитации крестьянства во время церковных проповедей против вступления в колхозы. Так, в информационной сводке о ходе сплошной коллективизации по Кадомскому району Рязанского округа от 13 февраля 1930 г. сообщалось: «Матчинский поп Елисеев на праздник крещения произнес проповедь, в которой призывал граждан воздерживаться от вступления в колхоз в течение года, а потом пойдет по старому. Старая Пошатовская церковь служит тайным сборищем кулацко-поповских собраний, куда стекается на совещание кулачество со всех окрестных селений» 2 .

В обзорах и донесениях ОГПУ отовсюду поступала информация о том, что церковники ведут активную агитацию против закрытия и осквернения церквей, насилия над религией, а провоцируемые ими возмущения среди крестьян в некоторых случаях «выливаются в форму массовых демонстраций с выпадами против Советской власти и с призывами “бить коммунистов”... В селе Вирюлевки, Гагаринской волости Скопинского уезда, священник Болагдовцев Петр Семенович, бывший офицер, в своих проповедях ведя агитацию против безбожия, выступает против Советской власти. Он говорит: “Советская власть, это власть не от Бога, власть временная, поэтому ей можно и не подчиняться. Недалеко то время, когда декретами Советской власти и червонцами на посмешише людям будут заклеивать заборы”»3.

Между тем положение духовенства становится еще более тяжелым. Основанием для этого послужило постановление политбюро ЦК ВКП(б) «О мероприятиях по ликвидации кулацких хозяйств в районах сплошной коллективизации» от 30 января 1930 г., в котором давалось прямое указание о повсеместном закрытии церквей: «Поручить Оргбюро ЦК дать директиву по вопросу о закрытии церквей, молитвенных домов сектантов и проч. и о борьбе с религиозным и сектантским движением, в целях устранения тормозов в соваппарате, мешающих проведению в жизнь принятых подавляющей массой крестьянства решений о закрытии церквей, молитвенных домов сектантов и т.п.» 4 .

Ко всем существующим бедам духовенства добавились прямые репрессии: их

1 Государственный архив Рязанской области (ГАРО). Ф. Р-2442. Оп. 1. Д. 17. Л. 128.

2 ГАРО. Ф. Р-5. ОП. 1. Д. 292. Л. 118.

3 Рязанская деревня в 1929 - 1930 годах. Хроника головокружения: документы и материалы. М.: РОССПЭН. 1998. С. 32.

4 Трагедия советской деревни. Коллективизация и раскулачивание. 1927-1939: документы и материалы. В 5 т. М.: РОССПЭН. Т. 2. 2000. С. 130. 
раскулачивание и выселение из занимаемых домов, аресты, тюремные заключения и высылка из районов проживания. В ответ священники массово апеллировали к крестьянским массам, причем формы подобных призывов изменились. Отказываясь от открытых антибезбожных, антисоветских и антиколхозных проповедей, священничество действовало через сельское население приходов, главным образом через женщин, как правило из бедняцкого или середняцкого слоя деревни, используя их в качестве проводников своих интересов, распуская слухи о скором закрытии церквей, о предстоящем голоде в колхозах, клеймении там детей, насилии над женщинами и т.п. Мы можем привести информацию об уже упомянутом выше сельском священнике А.Е. Инякине. В докладной записке в Рязанский окружком ВКП(б) констатировалось: «...в селе Нармушади главный виновник систематической агитации против колхоза был поп Инякин, он свою работу проводил через беднячку Авдееву... Авдеева сидит до сих пор, а поп гуляет на свободе, очевидно, помогает строить колхозы» ${ }^{2}$.

Иногда местное духовенство, оказываясь в критической для себя ситуации, проявляло изобретательность. Так, в сводке Рязанского окружного исполкома сообщалось о том, как бригадиры по коллективизации явились вечером к священнику сел Деулино и Картаносово для описывания имущества перед раскулачиванием. Поп, бывший в то время на крестинах, узнав об их приходе, объявил окружающим, что это пришли его арестовывать: «Бабка-повитуха и церковная сторожиха собрали толпу женщин человек 300, которая окружила бригадиров, крича “Бей их”. Никакие уговоры не действовали и только прямая угроза оружием заставила женщин разойтись и спасла бригадиров от избиения» ${ }^{2}$.

На фоне мощного давления со стороны органов власти, а также осуществляемых в отношении священников акций насилия в ведомственных сводках отмечалось, что среди сельского духовенства начинается сильная апатия: «Некоторые попы, подлежащие аресту, сбежали. Церковники распространяют слухи о том, что служат в церкви последний раз и объявляют поголовное причастие... Вообще же настроение духовенства паническое, за последнее время (к середине января) усилилось бегство попов (снятие сана), приняв массовый характер. За февраль месяц зарегистрировано два случая самоубийств попов».

Снявшись с насиженных за многие десятилетия мест, священничество пыталось найти себе новое, пусть даже временное, прибежище. Об этом свидетельствует информационное сообщение о ходе сплошной коллективизации по Рыбновскому району Рязанского округа от 28 января 1930 г.: «Село Пощупово... Большое влияние имеет монастырь, куда стекаются разные слои. Особенно наблюдается за последнее время в связи с отказом многих попов от несения службы по другим селениям. Под видом помолиться эти антисоветские слои темным путем распространяют разного рода слухи, которые влияют на население села Пощупово» 3 .

Жители деревни, между тем, в основной своей массе не оставались безучастными к репрессиям и насильственным акциям со стороны представителей местной власти и деревенских активистов в отношении церкви, а в ряде случаев давали последним отпор. Это наглядно показывает следующий пример из стенограммы первого съезда колхозников-комсомольцев Московской области, проходившего с 30 ноября по 2 декабря 1929 г.: «В Валовском районе, селе Непрядьеве, комсомольцы забрались в церковь, сняли иконы и орга-

\footnotetext{
1 Рязанская деревня в 1929 - 1930 годах. Хроника головокружения: документы и материалы. М.: РОССПЭН. 1998. С. 159.

2 Там же. С. 339.

3 ГАРО. Ф. Р-5. Оп. 1. Д. 292. Л. 93.
} 
низовали значительную иллюминацию. Узнав об этом, крестьянство ударило в набат, собралось около церкви более 200 человек крестьян. Комсомольцы заперлись внутри церкви. Крестьянство, вооружившись кувалдами, стало разбивать дверь с тем, чтобы изъять, сделать по их выражению соответствующие “организационные выводы”. И только благодаря быстрому приезду местных властей удалось спасти этих энтузиастов, революционеров в кавычках» ${ }^{1}$.

Указанный случай имел некоторый резонанс только благодаря решительному отпору, полученному активистами от крестьян. Когда же крестьяне безропотно терпели подобные выходки комсомольцев, то подобные факты не выходили за переделы сводок в местные окружные комитеты ВКП (б): «В Юхнове комсомольцы возглавили снятие икон у крестьян, собрали шесть подвод икон, облили керосином и сожгли. В другом месте то же самое - ряд безобразий, снимали колокола и т.д.» ${ }^{2}$.

После публикации статьи И.В. Сталина «Головокружение от успехов» 2 марта 1930 г. наблюдалось заметное ослабление давления как на крестьянство, что явилось следствием массового его оттока из колхозов, так и на духовенство. Наступило время краткосрочной «оттепели». К маю месяцу содержание прежних сводок ОГПУ о массовом характере оставления священнослужителями своего сана и о том, что духовенство стало очень осторожным, стало меняться на сообщения о появившихся у последних оптимистических настроений: «Зато среди церковников - оживление. Они настойчиво требуют открытия незаконно и даже законно закрытых церквей. В некоторых селениях устраиваются крестные ходы и молебны о дожде (май месяц был очень засушлив, что сказалось на посеве)... Приняты меры к тому, чтобы все церкви, закрытие которых не оформлено установленным порядком, были возвращены верующим 3 .

Представляется, что в изучении контекста указанной социальной трансформации актуально определение российской ментальности, характера русского населения, основанного на глубинных почвеннических основаниях (любовь к родной земле, влияние религиозности на общественное сознание, особенности мировоззренческого восприятия мира внутри сельского социума, значение моральных и нравственных императивов в поведении жителей деревни) [Васильев, Васильева 2014].

Более крепкие и стойкие представители сельского духовенства воспряли духом с приходом временной «оттепели» и начали открыто заявлять властям о своих требованиях и правах. Были и те, которые надломились окончательно и которым уже не суждено было стать прежними. Для подобного примера мы еще раз обратимся к тексту жалобы сельского священника Андрея Егоровича Инякина на неправомерное раскулачивание, поданной на имя окружного прокурора. Как отмечалось выше, ранее он агитировал крестьян против вступления в колхоз, потом был раскулачен, причем у него было отобрано все движимое и недвижимое имущество вплоть до «ручных салфеток... и... нитяных чулок». Он вместе со всем своим семейством в «зимнее холодное время были выгнаны на улицу полураздетые, полуобутые, оставалось замерзать и только люди чужие дали им приют... Семья в это время была отправлена в тюрьму города Касимова, где совершенно без вины находилась до 17 мая и освобождена без всякого суда. Мне от роду 78 лет, я болен грыжей, ревматизмом в руках и ногах и убоем в левом боку от падения... Состоял я до сего времени служителем

1 Центральный государственный архив г. Москвы. Ф. ІІ-634. Оп. 1. Д. 268. Л. 160.

2 Российский государственный архив социально-политической истории. Ф М-1. Оп. 2. Д. 81. Л. 32.

3 Рязанская деревня в 1929 - 1930 годах. Хроника головокружения: документы и материалы. М.: РОССПЭН. 1998. С. 609. 
культа (священником), служу единственно из насущного куска хлеба, получая самое ничтожное вознаграждение. В настоящее время я не имею крова, разут, раздет и нет никаких средств к дальнейшему существованию... Принимая во внимание все выше изложенное, покорнейше и почтительнейше прошу Ваше Прокурорское воздействие войти в мое положение исключительно тяжелое, сделать соответственное распоряжение о возвращении отобранного крова... это мое единственное достояние, в этом заключаются все мои средства к дальнейшему существованию меня, старика 78 лет, больного; больной и слепой 75 летней жены и дочери, девицы Любови 43 лет, душевнобольной» ${ }^{1}$.

Перед нами предстает уже не священник, не «пастырь человеческих душ», а разбитый, растоптанный, унижающийся перед светским начальством старик, подобострастный и заискивающий, который ради призрачных земных благ (скорее всего он понимает, что едва ли может надеяться на то, что хотя бы часть из отобранного имущества ему вернут) готов отказаться от веры, сам себя называющий «служителем культа», «покорнейше» и «почтительнейше» просящим вернуть ему отобранный кров.

Резюмируя вышеизложенное, можно отметить, что сельское священничество в период «великого перелома» состояло из самых обычных людей, которые в ответ на вызовы своего времени реагировали по-разному. Они так или иначе пытались защитить свое жилище и имущество, свою церковь, свое право продолжать служить там, противостоять нападкам государства. Для каждого человека, конечно, был свой предел. Если в течение 1929 г., когда маховик репрессий был еще не сопоставим по своей силе с таковым в начале 1930 г., духовенство массово протестовало против политики, проводимой советской властью в отношении церкви. В критический момент первых месяцев 1930 г. проявился широкий спектр реакций - от борьбы за свое существование с привлечением на свою сторону крестьянских масс до покорности духовенства перед проходящим по ним катком репрессивной государственной политики, что проявилось на примере священников, отказавшихся от служения и ушедших в монастырь.

\section{Список литературы}

Алешкин П.Ф., Васильев Ю.А. 2012. Крестьянские восстания в России в 1918 1922 гг. От махновщины до антоновщины. М.: Вече. 400 с.

Васильев Ю.А., Васильева М.Ю. 2014. Влияние идей Христиана Вольфа на мировоззрение М.В. Ломоносова. - Власть. № 3. С. 121-125.

Васильев Ю.А., Шепелев В.Н. 2016. Борьба политических элит в условиях позднего сталинизма. Карельский отголосок «Ленинградского дела». 19491950 гг. - Исторический архив. № 3. С. 3-31.

\footnotetext{
${ }^{1}$ ГАРО. Ф. Р-2442. Оп. 1. Д. 17. Л. 128.
} 
STROGANOV Aleksei Valer'evich, postgraduate student of the Chair of History and Regional Studies, Moscow University for the Humanities (5 Yunosti St, Moscow, Russia, 111395; stroganovalexey@yahoo.com)

\title{
THE ROLE OF THE CLERGY IN THE PEASANT PROTEST DURING THE COLLECTIVIZATION PERIOD
}

\begin{abstract}
The article presents an interpretation of the relationship between the government and the clergy in the conditions of the "great turning point» announced in the USSR, which marked the beginning of complete collectivization. On the base of archival materials and documentary publications, the author states that the scale of repressions against rural priests is not comparable with that one at the beginning of 1930s, which resulted in a massive protest of the clergy against the policy of the Soviet government in relation to the church. However, the struggle for existence, attracting the peasant masses to its side were often combined with manifestations of the submissiveness of the clergy in relation to the repressive state policy. Keywords: collectivization, Russian village, state, power, protest, rural clergy, church, peasantry
\end{abstract}

ВАГАПОВА Фирдаус Габдуллазяновна - кандидат филологических наук, доцент кафедры международных отношений, мировой политики и дипломатии Института международных отношений Казанского (Приволжского) федерального университета (ИМО КФУ) (420008, Россия, Республика Татарстан, г. Казань, ул. Пушкина, 1/55, корп. 312; yaktashlar@mail.ru)

ВАГАПОВ Ренат Наильевич - кандидат политических наук, советник отдела профилактики экстремизма на религиозной почве управления мониторинга в сфере межнациональных и межконфессиональных отношений Федерального агентства по делам национальностей (ФАДН) России (125039, Россия, г. Москва, Пресненская наб., 10, cmp. 2; renariov@gmail.com)

\section{ФОНД ПОДДЕРЖКИ ИСЛАМСКОЙ КУЛЬТУРЫ, НАУКИ И ОБРАЗОВАНИЯ КАК ФАКТОР САМОСТОЯТЕЛЬНОСТИ МУСУЛЬМАНСКОГО ДУХОВЕНСТВА РОССИИ В ПРОТИВОСТОЯНИИ КОРРУПЦИИ}

Аннотация. В статье рассматриваются механизмы противостояния коррупции, системного противодействия распространению идеологии религиозного экстремизма и радикализма в сфере общественно-политических отношений в Российской Федерации, которыми обладает Фонд поддержки исламской культуры, науки и образования.

Ключевые слова: Фонд поддержки исламской культуры, науки и образования, противодействие коррупции

Согие годы антирелигиозной пропаганды привели к тому, что в 1990-х гг. 1 в Российской Федерации резко активизировалось массовое появление и регистрация религиозных организаций в связи с бесконтрольностью идеологической части со стороны органов государственной власти. В силу размытых законодательных норм в число данных организаций вошли создаваемые духовные управления и общественные организации мусульман, придерживающиеся 